\section{Transnational migration of health professionals in the European Union}

\author{
Migração transnacional de profissionais de saúde \\ na União Européia
}

\footnotetext{
1 Institute of Medical Sociology, University of Frankfurt, Frankfurt am Main, Germany.

Correspondence T. Gerlinger Institute of Medical Sociology, University of Frankfurt.

Haus 9 B, Theodor-Stern-Kai 7, 60590 Frankfurt am Main, Germany.

gerlinger@em.uni-frankfurt.de
}

\begin{abstract}
The establishment of the European Common Market has involved the free movement not only of capital and goods, but also of persons and services. The principles of free movement also apply to the health care sector, i.e. they allow for the free incorporation of health care providers and the cross-border delivery of services. Since the 1970s, the European Union (EU) has passed numerous regulations to enforce the mutual recognition of qualifications of physicians, nurses, and other health professionals by the Member States, considered an indispensable precondition for the free movement of services. Thus far, the establishment of a European job market for the health care professions has not led to extensive migration among the EU Member States. Likewise, the accession of Central and Eastern European countries to the EU in 2004 did not cause a "brain drain" to the better-off countries of Western and Northern Europe. However, the mobility among health care professions is expected to increase in the coming years.
\end{abstract}

European Union; Migration; Human Resources
Thomas Gerlinger 1

Rolf Schmucker 1

In the area of general social policy and health care policy in particular, competence is only slightly developed at the European level 1. It is true that, according to the European Treaty, the European Union (EU) is obliged to improve public health and to ensure a high level of health protection in all fields of Community policy. In a few areas, namely workplace health and safety and consumer protection, it is even entitled to set minimum standards for the Member States. However, even in the few fields where the EU exerts explicit regulatory authority, it only plays a subsidiary role, limited to promoting cooperation among Member States and complementing national policies. In general it is only allowed to take action where European activity is supposed to produce better results, rather than act at the Member State level. Moreover, member states still retain the competence to shape their national health care systems, e.g. the organization of health care delivery including the institutional organization of care and the division of labor among the various occupational groups 2 .

Nevertheless, the EU is not unimportant in the field of health policy. The EU derives its influence mainly from the provisions of the Common Market and the Economic and Monetary Union (EMU). The creation of the Common Market in 1992 not only provided for the free movement of capital and goods, but also of people and services, the so-called "four freedoms". These principles also apply specifically to the health care sector. 
Therefore, the authority of Member States to shape their health care systems cannot be equated with unlimited freedom of action. The European Court of Justice has ruled that Member States must abide by the principles of free movement of goods, services, capital, and persons when exercising their authority. Thus, economic integration limits the member states' freedom of action in health policy. The current text analyzes the effects of European integration on transnational migration of health professionals and the attempts to regulate it.

\section{Provisions on recognition of diplomas and certificates}

The free movement of persons implies that health professionals, as a part of the European workforce, can move across borders and work in other Member States. Against this background, since the mid-1970s the EU and Member States have attempted to reach agreements on the mutual recognition of certificates and diplomas of health professionals.

Since 1975 a considerable number of directives have been adopted, and amended, governing the mutual recognition of the various occupational certificates for physicians 3,4 , dentists 5 , pharmacists 6 , nurses 7,8 , and midwives 9 . These directives contain extensive and detailed educational requirements for specific occupations, prerequisites for admission, duration, and scope of training, and occupational titles. They are thus called "sectoral directives". They set minimum standards that are binding for the Member States, which in turn may raise the standards further within their sovereign territories. In addition, the directives include regulations for the automatic recognition of occupations in the health sector. However, the Member States may not use their higher national standards to discriminate against graduates from other countries who fulfill the minimum European standards, but not the higher standards of the respective country (such a case could lead to a "discrimination in favor of nationals", i.e. the establishment of advantages for the domestic labor force on the labor market). For the study of medicine, for example, these sectoral directives stipulate a minimum of five years study and 5,500 hours of training. For nursing, the minimum standard is three years of training consisting of at least 4,600 hours in theoretical and practical training 8 .

The most important obligations for mutual recognition of certificates for physicians are provided in the so-called "physicians directive" 4 , passed in 1993 and stipulating the automatic recognition of diplomas and certificates of physicians. This automatic recognition applies when: - The physician is a citizen of one of the Member States;

- The diploma in question is a qualification from one of the Member States;

- The training was done in one of the 52 specialties listed in the appendix of the directive both for the country of origin and the target country.

Due to the diverging interests of the Member States and the extra workload associated with negotiating these sectoral directives, regulation turned out to be difficult and the mutual recognition of qualifications made little headway. In the late 1980s and early 1990s, these problems led the European institutions to shift their policies. They now relied heavily on the so-called "general directives", dispensing with requirements for harmonizing course and training contents. Instead, they operate under the assumption of uniformity of qualifications based on common admissions requirements for the respective occupations and the acquired qualification. They limit themselves to distinguishing between a university diploma based on three or more years' study 10 versus less than three years 11 . The power of recognition now lies with the Member States. If, in the recipient country, the occupation is not normally acquired as basic training, it is incumbent on that country to examine the qualifications of the person wishing to immigrate and to refuse permission to practice this occupation or to impose certain conditions (e.g. further training or aptitude tests).

Finally, in September 2005 the European Council 12 re-regulated the recognition of 150 occupations, included medicine and nursing. The directives previously regulating the recognition of certificates were repealed under the new provisions. Nevertheless, these provisions do not change considerably for health professionals, because they confirm the principle of automatic recognition for all existing specialties. Still, for the recognition of new specialties, the bar was now set higher. For these certificates, automatic recognition is guaranteed only if at least ten member states have introduced the new title (the so-called "two-fifths regulation"). If this is the case in less than ten countries, practicing this specialty in another Member State is possible only if a bilateral agreement exists or if the authority in the country in which the physician desires to practice issues an appropriate permit. Poor countries can use this provision as a means to hinder the emigration of their medical and nursing staff. By "inventing” a new occupational title or specialty which only exists in a few member states they may lead other Member States to 
refuse job immigration for the respective groups of health professionals.

Overall, Europeanizing the recognition of diplomas contributed to a certain convergence of certification in health care occupations and improvement in training. Meanwhile, considerable differences in certain areas of education between the Member States still persist. This applies particularly to regulations on training in general medicine, which varies quite widely among member states. In Germany or Denmark, five years of postgraduate training are required, while in Italy or Sweden, qualification in general medicine can be obtained in just two years. According to European law, both are entitled to practice general medicine in any EU Member State.

\section{The increasing importance of transnational migration of health professionals}

The migration of physicians and nurses has been discussed for decades at the international level. In 1978, the World Health Organization (WHO) first published data on the global migration of health professionals. Surprisingly, in the 1970s the health care sector experienced a large increase in migration among all the highly skilled professions. In particular the number of migrating physicians and nurses increased significantly ${ }^{13}$. This global trend has continued since then and is expected to increase even further in the future. The "brain drain" of physicians and nurses has already increased the shortage of health personnel in several parts of the world, mainly in Africa and Asia 14,15,16,17. The effects on already scarcely developed health care delivery in poor countries can be serious. "When a country has a fragile health system, the loss of its workforce can bring the whole system close to collapse and the consequences can be measured in lives lost. In these circumstances, the calculus of international migration shifts from brain drain or gain to 'fatal flows'” 17 (p. 101).

Apart from North America, the affluent Western European countries are the preferred destination for health professionals from poorer regions of the world. According to the European Commission, the need for qualified health professionals is expected to increase in the future. "The problems with recruitment and retention of medical personnel, which are already being felt in some Member States, are likely to be accentuated by the overall trend towards an ageing and shrinking workforce in this sector, resulting in the competition for manpower becoming tougher. Both trends could increase costs. Thus, the health sector will have to adjust to the impact of ageing on its personnel as well as on its clientele. This is particularly true for nurses: In seven Member States forty per cent of nurses are already more than 45 years of age and in another five Member States almost one in two nurses have reached this age. Two other factors contribute markedly to the shortages of nurses: 'Stop-go' trends in recruiting policies and most importantly: demanding working conditions in combination with moderate pay leading to a high staff turnover. The recruitment of immigrants to fill shortages in this sector is likely to grow in importance" 18.

Motives for migration can be attributed to various push-pull factors. Push factors which may cause health professionals to leave their country are low pay, poor working conditions, lack of health care resources, limited career prospects, economic instability, a hazardous work environment, and the prevalence of infectious diseases like HIV/AIDS. Correspondingly, pull factors which make a country attractive to health professionals are better pay (and thus the possibility to provide for relatives), better working conditions, a well-equipped health care sector, good chances for further qualification, positive career prospects, and political and economic stability 19 .

\section{Transnational migration of health professionals in the European Union}

In the past, health professional immigrants in the EU mostly came from poorer countries outside the EU. Although the push-pull factors mentioned above also functioned within the EU, immigration of health professionals from one EU Member State to another was relatively limited.

\section{EU expansion 2004: expectations and fears}

However, this situation is felt to be changing with the EU expansion. The accession of ten new members from Central, Eastern, and Southern Europe in May 2004 significantly widened the gap between rich and poor member countries. In 2003, the per capita GDP of the "EU 15", i.e., the pre-expansion Member States, was roughly twice that of the applicant countries. Meanwhile, the unemployment rate in the EU was 8 per cent as compared to 14.3 per cent on average in the applicant countries (Eurostat. http:// europa.eu.int/comm/eurostat, accessed on 30/ Jun/2004). Following the demise of Socialism, the health care systems of the Central and Eastern European Member States have been fundamen- 
tally changed. Meanwhile, the crisis in public finance with economic instability, high unemployment rates, and relatively low wages has led to a lack of resources for medical institutions. On average, the working conditions and pay for health care system employees in applicant countries are significantly worse than those of the "old" Member States. Job satisfaction among health professionals is also considerably lower 20 . Thus, health professionals from the accession countries, especially the new Central and Eastern European members, are subject to strong push-pull factors, increasing the probability of migration to the "old" Member States.

The potential effect of EU membership on social protection systems in applicant countries was discussed in the EU before expansion. Due to differences between health care systems in the 25 Member States, many authorities expected a mass migration of health professionals from the accession countries. A study ordered by the European Commission concluded: "Membership of the EU brings with it the right to the free movement of people, goods and services anywhere within the EU borders. This right has implications for the movement of both health professionals and patients across borders. In terms of health professional movement, examination of patterns within the current EU Member States shows very low levels of migration. However, the candidate countries now preparing for accession have, in general, a much lower level of funding available for health care resources and staff salaries compared with other recent new EU members such as Austria and Finland. Consequently, fears have been raised that there may be widespread professional movement from some candidate countries to more well off current EU Member States with staff shortages" 21.

A survey by the Open Society Institute carried out in several applicant countries in 2002 showed that many physicians were prepared to go to another Member State after their country joined the EU. In the Czech Republic, Hungary, Lithuania, and Poland, 25 to 50 per cent of interviewees stated that they were considering migration to another EU country. Five to ten per cent of physicians were determined to leave their country ${ }^{19}$. Even before joining the EU, after the demise of Socialism, many health professionals had looked for a new job in Western European EU countries. Due to the forthcoming free movement of employees, this trend was expected to increase beginning in 2004. Several country reports expressed the fear that EU expansion would lead to a brain drain of qualified professionals - e.g. with regards to Hungary: "The other negative effect would be the health professionals' migration especially nurses into Austria and Germany, or physicians into other countries too. If the government will not effectively tackle the 'salary problem, the migration of the health professionals could become a permanent phenomenon" 22 . However, the forthcoming free movement of health professionals was not only seen to be disadvantageous. In particular, the intensified exchange of knowledge and skills, the chances for international education, the return of more highly qualified professionals, and the more rapid implementation of new medical procedures were seen to improve the quality of health care 23,24 .

\section{Transnational mobility of health} professionals: empirical evidence

Two years after the EU expansion, we may ask whether the expectations and fears about increasing migration of health professionals have been confirmed. It is true that the available data are insufficient. There are no comparable data for the EU as a whole, and WHO and Organisation for Economic Co-operation and Development (OECD) also lack detailed evidence of transnational migration of health professionals 25 . However, country statistics and case studies enable us to identify some basic trends, which will now be illustrated considering Great Britain and Germany as target countries and Poland and the Baltic States as Eastern Europe countries of origin.

Germany is basically regarded as a target country for migration in the health care sector, although this does not conceal the fact that an increasing number of German health professionals are going abroad (more than 12,000 German physicians are now working abroad, mostly in the UK, Sweden, and USA 26). Some 4.1 million people are now working in the German health care sector, 226,000 (five per cent) of which are foreigners 27 . The share of foreign physicians was about six per cent in 2005. In Germany, only 18,582 of 307,577 practicing physicians were foreigners. More than $40 \%(7,554)$ of these foreign physicians were from EU countries, with the largest groups from Greece $(1,358)$, Austria $(1,269)$, and Poland $(1,171)$. In short, only 2,114 came from the newly admitted Eastern European member countries. Nearly $30 \%$ of foreign physicians in Germany came from non-EU European countries, with those from the former Soviet Union forming the largest group $(1,572)$. The remaining $30 \%$ of foreign physicians in Germany were from Asia (3,818, including 1,201 from Iran), Africa (813), and the Americas (655) 28.

The effect of the EU expansion is not expressed precisely in the statistics on German physicians. A total of 2,160 physicians from candidate countries were working in Germany in 2005. 
This was an increase of nearly 500 as compared to 2003. Individual countries are involved in this trend to different degrees. While the number of physicians from the Baltic States, Slovenia, and Hungary tended to remain stable, immigration from Poland, the Czech Republic, and Slovakia increased significantly. Obviously, EU expansion has reinforced the trend of physicians migrating from these countries 28 . This migration is being fueled by the recruitment activities of German institutions in response to the emerging shortage of doctors in some areas of East Germany.

When migration does occur, it is quite rare for health care professionals to become self-employed (as physicians in private practice, for example) in a foreign country. They usually work in hospitals or nursing institutions. In Germany, only 3,437 foreign doctors run private practices (2.7\% among the total of 126,252 office-based doctors). The share of foreign doctors is considerably higher in the hospital sector: 10,309 out of $146,511(7 \%) 28$. As for nurses, the share of foreigners was $6.7 \%$ for care of the elderly and $5.3 \%$ of hospital nurses in 2004, as compared to $8.2 \%$ of foreigners in the total German labor force that year 29 .

There is a longstanding tradition of recruiting foreign health professionals in Great Britain, where the National Health Service (NHS) attempts to compensate for the short supply of domestic health professionals without having to bear the costs for training these employees. This applies especially to nurses, but also to physicians. Compared to Europe as a whole, the percentage of foreign physicians and nurses in Great Britain is far above the average. However, this is also partially due to the widespread knowledge of the English language among health professionals, especially physicians, from countries in which English is not the native language. Thus, numerous German physicians have gone to work in Great Britain in recent years. Roughly one third of physicians working in the NHS are foreigners 28. Recruitment is concentrated on English-speaking countries. In 2001, the largest share of foreign doctors (18.3\%) was from India. Irish physicians accounted for $15.2 \%$ of foreign doctors in the NHS. The share of doctors from Africa working in the NHS is strikingly large: nearly $20 \%$ from Africa as a whole, with $7 \%$ from South Africa alone 30 . The British Department of Health has issued a Code of Practice on International Recruitment for the NHS, according to which it is not allowed to recruit workers from developing countries. However, the provisions are full of loopholes and in practice are often circumvented. For example, the NHS demand for foreign health workers leads to emigration of (South) African professionals and thus jeopardizes the quality of health care in the countries of origin 15. Despite the free movement of people in the EU and the accession of ten new Member States, most foreign workers in the NHS come from the Commonwealth countries, especially the Philippines, South Africa, and Australia. In 2002, almost 50\% of nurses in Great Britain were foreigners, and $13 \%$ were from EU countries 31 .

To a certain extent, immigration from Germany is a special case, in which recruitment began when there was an oversupply of physicians. Although this situation changed in recent years and there are even fears of a future lack of doctors, German doctors continue to be recruited for the NHS 19. The increasing number of physicians deciding to work in Great Britain can be attributed to effective push factors in Germany. Work strain and widely spread dissatisfaction towards pay lead an increasing number of German physicians to decide to work in Great Britain, at least temporarily. Previously, the immigration of health professionals from the Central and Eastern European states was not very important for Great Britain, but there are initial signs that the share of Polish physicians in the NHS is increasing 25 .

Before their accession to the EU, the then-applicant countries expected a massive migration of health specialists to the "old" Member States. However, a brain drain did not occur in the first year after accession. Especially in Poland and the Baltic states, the number of physicians and nurses going abroad was smaller than expected by authorities from these countries, but the trend towards migration from Poland was most obvious: in 2004-2005: $7.7 \%$ of health professionals (physicians, dentists, and nurses) had the relevant authorities issue a certificate for international recognition of their professional qualifications. This does not allow for a statement about the real extent of emigration, but can be regarded as an indicator that many workers are seriously considering emigration. Aside from the "old" EU Member States, Australia and the United States also attract Polish nurses. Nevertheless, emigration from Poland has so far been only of minor importance 25 .

The Baltic countries also report that actual migration in the health sector has fallen short of predictions. In quantitative terms, migration has remained low and is far from the biggest problem these states are facing with health care staffing. For example, in Estonia, it is much more relevant that a large share of health professionals shift to other sectors of the economy. Thus, push factors like poor working conditions and low pay produce not only emigration, but other reactions as 
well. In order to increase the incentives for health professionals to stay in their home countries, the national governments are attempting to improve the local working conditions. "Poland reported improving working conditions; Lithuania reported a policy of salary increases, facilities renovation with new equipment and offices for general practitioners; Estonia reported pay increases in January 2005 and similar efforts have been reported in Latvia" 25 (p. 10). Obviously, the fear that health professionals might emigrate is an important motive for national governments to reform the domestic health care sector 32 .

In summary, free movement of health care occupations has not led thus far to massive transnational migration of health professionals in the EU.

This can be attributed to various factors:

- Language barriers play a much bigger role in health care than in most other sectors, especially because these occupations deal on a personal level in a particularly sensitive area;

- Additionally; as in many other occupations, geographic proximity between the country of origin and the target country makes it easier to emigrate;

- Finally, some countries have restricted the immediate unlimited free movement for employees from the newly admitted member states because of concerns that the job market may not be able to handle immigration from neighboring countries. Thus, Germany and Austria have introduced a five-year transition period during which immigration from Member States is not allowed. This period may be extended for another two years. Other Member States like Italy have restricted the total number of immigrant professionals to an annual maximum. Spain and Greece are especially interested in limiting immigration of foreign physicians and nurses because they already have quite a large supply of qualified health care employees. Thus, free movement of persons has not materialized completely for all Member States.

But European integration involves not only the free movement of health care professionals. Pursuant to several decisions by the European Court of Justice, EU citizens have the right to receive health care services according to the regulations in their country of origin 33 . This opens the way for cross-border health care services in the other direction, whereby patients can seek care in other EU countries and thereby reduce waiting periods or treatment costs. Thus far, generally speaking this possibility has only been used moderately, although this form of "health tourism" has increased for dental care. Particularly for dental prosthetic work, where patients have to bear a large portion of the costs out of pocket, they tend to take advantage of price differences (often quite large) between Member States. Otherwise however, cross-border use of services is only significant in regions near the border. The reasons for the relatively minor importance of "health tourism" are obvious:

- Here again, there are usually language barriers;

- In most cases, transaction costs (travel time and expenses) are too high for the services to be an advantage to the patient;

- For most medical conditions, no significant difference in the quality of treatment is expected

\section{The conflict around the EU Services Directive}

Although there is a European job market for health care professions, most Member States attempt to raise barriers to mobility. This applies both to establishing a business and to providing services in another Member State (target country). Such barriers mostly involve extensive bureaucratic requirements 34 . For example, business permits are often contingent on the applicant providing comprehensive information in the target country's language. The main intent of such requirements is to protect local service providers from foreign competition. This does not apply to all Member States and all sectors of the economy, but if a country is keen on limiting job immigration from a EU Member State, it often acts by this means.

Against this background, in 2004 the European Commission released a Draft Services Directive 35 , which aims to foster a common services market. It prohibits setting arbitrary requirements for establishing a business or delivering services in another country. But the core of the directive is different. For services (including health care) in which providers from a country of origin perform in a target country, it provides for the so-called country-of-origin principle. Accordingly, the service provider may provide services under the terms and conditions that apply in his country of origin. Regulation of health care services is left to the country where the service provider settles, not to the country where the service is delivered. This applies to both quality of services and employment conditions (working conditions, including working time and wages). A Polish nursing care company could thus provide services in Germany with employees who work according to Polish conditions. German authorities would have no influence on either the working conditions or the services provided. 
Hence, the services directive became a matter of vigorous controversy and led to a major conflict at the European level and in Member States. While economic liberals supported the directive, strong opposition came mainly from parties on the left and trade unions in the more affluent Member States. They feared that it could lead to a decline in the quality of health care and to social dumping in employment conditions ("race to the bottom") because - to use the same example German nursing services whose employees work shorter hours for higher wages would then have to compete with Polish nursing services (with longer working hours and lower wages). With this conflict escalating, in spring of 2006 the European Council finally adopted a Services Directive with two major amendments. First, the countryof-origin principle was toned down by obliging the target country to ensure the free movement of persons who wished to establish a business or provide services in another Member State; second, the health care sector was excluded from the scope of the directive.

But this does not mean in any way that the liberalization of health care services within the EU will not continue. On the contrary, at the same time when the Services Directive was adopted the European Commission decided to make new specific regulations for the health care sector only. The draft for a new directive is currently in progress. It is supposed to adhere to the country-of-origin principle and is expected be issued in 2007. If the establishment of businesses and provision of services in other Member States continues to be liberalized, migration of health professionals is expected to increase considerably.

\section{Conclusion}

The principles of free movement also apply to the health care sector, i.e. they allow for the free settlement of health care providers and the crossborder delivery of health care services. Since the 1970s, the EU has issued numerous regulations to enforce mutual recognition of qualification for physicians, nurses, and other health profession- als by the Member States in order to facilitate the free movement of such professionals. Although data on migration in the EU are incomplete and it has been only two years since the new Member States have joined the Union, some trends can already be identified. After EU expansion in May 2004, the migration of health professionals increased, but not to the extent expected. Thus far, in terms of migration between EU Member States, the brain drain has failed to materialize. Meanwhile, immigration of health professionals to the EU from countries outside the Union is of major importance. Especially in Great Britain, immigration from the Commonwealth countries predominates, while in Germany many health professionals come from Eastern European (former Soviet Union) non-EU Member States. For professionals from the Central and Eastern European EU Member States, non-European countries (e.g. United States, Canada) are also attractive targets for emigration.

Obviously, knowledge of the respective foreign language and geographic proximity to the target country play an important role in the decision to emigrate.

National governments react to migration in different ways. Some target countries conduct a foreign recruitment policy, while others attempt to raise barriers to immigration. The countries of origin are mostly interested in limiting the emigration of their domestic health care workforce. The consequences of demographic change for the European population (decreasing supply of professionals, increasing demand for health care) and further liberalization of the European health care sector can be expected to increase the mobility of the health sector workforce in the future. If net migration from the poorer to the wealthier Member States increases in work market sectors where there is a shortage of workers, the larger reservoir of qualified workers will increase the pressure on income levels in this sector in the wealthier countries. The continuing emigration of qualified medical and nursing professionals poses the risk of a "brain drain" which could jeopardize the quality of health care in the newly admitted Member States. 


\section{Resumo}

A criação do Mercado Comum Europeu envolve a circulação livre tanto de capital e produtos quanto de pessoas e serviços. Os princípios da circulação livre se aplicam igualmente ao setor de saúde, i.e., permitem a incorporação livre de provedores de assistência e a prestação transfronteiriça dos serviços. Desde os anos 70, a União Européia (UE) tem aprovado várias normas voltadas para o reconhecimento recíproco da qualificação de médicos, enfermeiros e outros profissionais de saúde pelos Países Membros, como précondição indispensável para a movimentação livre de serviços. Até o momento, a criação de um mercado de trabalho europeu para as profissões de saúde não levou a uma migração extensa entre os Países Membros. A entrada de países do Leste Europeu e Europa Central para a UE tampouco provocou uma "fuga de cérebros" aos países mais abastados do Oeste e Norte do continente. Entretanto, a previsão é de que a mobilidade entre as profissões de saúde deve aumentar na Europa nos próximos anos.

União Européia; Migração; Recursos Humanos

\section{References}

1. Pierson P, Leibfried S. Mehrebenen-Politik und die Entwicklung des Sozialen Europa. In: Leibfried S, Pierson P, editors. Standort Europa. Sozialpolitik zwischen Nationalstaat und Europäischer Integration. Frankfurt: Suhrkamp; 1998. p. 11-57.

2. McKee M, Mossialos E, Baeten R, editors. The impact of EU law on health care systems. Brussels: Peter Lang; 2002.

3. European Council. Council directive 75/362/EEC of 16 June 1975 concerning the mutual recognition of diplomas, certificates and other evidence of formal qualifications in medicine, including measures to facilitate the effective exercise of the right of establishment and freedom to provide services. Official Journal of the European Communities 1975; 30 jun.

4. European Council. Council directive 93/16/EEC of 5 April 1993 to facilitate the free movement of doctors and the mutual recognition of their diplomas, certificates and other evidence of formal qualifications. Official Journal of the European Communities 1993; L 165/1.

\section{Contributors}

The authors drafted the paper jointly, and both introduced numerous changes after an in-depth discussion.
5. European Council. Council directive 78/686/EEC of 25 July 1978 concerning the mutual recognition of diplomas, certificates and other evidence of the formal qualifications of practitioners of dentistry, including measures to facilitate the effective exercise of the right of establishment and freedom to provide services. Official Journal of the European Communities 1978; L 23/1.

6. European Council. Council directive 85/432/EEC 16 September 1985 concerning the coordination of provisions laid down by law, regulation or administrative action in respect of certain activities in the field of pharmacy. Official Journal of the European Communities 1985; L 253/34.

7. European Council. Council directive $77 / 452$ /EEC of 27 June 1977 concerning the mutual recognition of diplomas, certificates and other qualifications of nurses responsible for general care, including measures to facilitate the effective exercise of this right of establishment and freedom to provide services. Official Journal of the European Communities 1977; L 176/1. 
8. European Council. Council directive 77/453/EEC of 27 June 1977 concerning the coordination of provisions laid down by law, regulation or administrative action in respect of the activities of nurses responsible for general care. Official Journal of the European Communities 1977; L 176/8.

9. European Council. Council directive 80/154/EEC 21 January 1980 concerning the mutual recognition of diplomas, certificates and other evidence of formal qualifications in midwifery and including measures to facilitate the effective exercise of the right of establishment and freedom to provide services. Official Journal of the European Communities 1980; L 33/1.

10. European Council. Council directive 89/48/EEC of 21 December 1988 on a general system for the recognition of higher-education diplomas awarded on completion of professional education and training of at least three years' duration. Official Journal of the European Communities 1989; L 19/16.

11. European Council. Council directive 92/51/EEC of 18 June 1992 on a second general system for the recognition of professional education and training to supplement directive 89/48/EEC. Official Journal of the European Communities 1992; L 209/25.

12. European Council. Council directive 2005/36/EEC from 7 September 2005 regarding the recognition of the professional qualifications. Official Journal of the European Union 2005; L 255/22.

13. Mejia A. Migration of physicians and nurses: a worldwide picture. Int J Epidemiol 1978; 7:207-15.

14. Patel V. Recruiting doctors from poor countries: the great brain robbery? BMJ 2003; 327:926-8.

15. Eastwood JB, Conroy RE, Naicker S, West PA, Tutt RC, Plange-Rhule J. Loss of health professionals from Sub-Saharan Africa: the pivotal role of the UK. Lancet 2005; 365:1893-900.

16. Fitzhugh Mullan MD. The metrics of the physician brain drain. N Engl J Med 2005; 353:1810-8.

17. World Health Organization. Working Together for Health. The World Health Report 2006. Geneva: World Health Organization; 2006.

18. European Commission. The social situation in the European Union 2003. http://europa.eu.int/ comm/employment_social/news/2003/sep/2003_ in brief_en.pdf (accessed on 10/May/2006).

19. Buchan J. Migration of health workers in Europe: policy problem or policy solution? In: Dubois CA, McKee M, Nolte E, editors. Human resources for health in Europe. Maidenhead: Open University Press; 2006. p. 42-62.

20. Hasselhorn HM, Müller BH, Tackenberg P, Kümmerling A, Simon M. Berufsausstieg bei Pflegepersonal. Arbeitsbedingungen und beabsichtigter Berufsausstieg bei Pflegepersonal in Deutschland und Europa. Bremerhaven: Wirtschaftsverlag NW; 2005.
21. Gesellschaft für Versicherungswissenschaft. Study on the social protection systems in the 13 applicant countries. Synthesis report. November 2002. http://ec.europa.eu/comm/employment_social/ news/2003/jan/report_03_en.pdf (accessed on 10/ May/2006).

22. Gesellschaft für Versicherungswissenschaft. Study on the social protection systems in the 13 applicant countries. Hungary. Country study. http:// ec.europa.eu/comm/employment_social/social_ protection/docs/hungary_final.pdf (accessed on 10/May/2006).

23. Zajac M. EU accession. Implication for Poland's healthcare personnel. Eurohealth 2002; 4:13-4.

24. Gesellschaft für Versicherungswissenschaft. Study on the social protection systems in the 13 applicant countries. Lithuania. Country study. http:// ec.europa.eu/employment_social/social_protection/docs/lithuania_final.pdf (accessed on 10/ May/2006).

25. World Health Organization. Health worker migration in the European region: country case studies and policy implications. Copenhagen: World Health Organization; 2006.

26. Kopetsch T. Studie zur Altersstruktur- und Arztzahlentwicklung: Daten, Fakten, Trends. http:// www.bundesaerztekammer.de/30/Aerztestatistik/ 02Arztzahlstudie/3Folien.pdf (accessed on 10/ May/2006).

27. Statistisches Bundesamt. Gesundheit. personal 2000. Wiesbaden: Statistisches Bundesamt; 2002.

28. Bundesärztekammer. Ärztestatistik. http://www. bundesaerztekammer.de/30/aerztestatistik/ (accessed on 10/May/2006).

29. Statistisches Bundesamt. Erwerbstätige nach Berufsordnungen und ausgewählten Merkmalen. Ergebnis des Mikrozensus. Wiesbaden: Statistisches Bundesamt; 2004.

30. Simoens S, Hurst J. The supply of physicians services in OECD Countries. OECD Health Working Papers, 21. http://www.oecd.org/dataoecd/ 27/22/35987490.pdf (accessed on 15/May/2006).

31. Buchan J. What's the connection? British nurse recruitment in an enlarged EU. Eurohealth 2002; 8 Special Issue:15-6.

32. Bach S. International migration of health workers: labour and social issues. Geneva: International Labour Office; 2003. (Working Paper, 209).

33. Busse R, Wismar M, Berman PC, editors. The European Union and health services. Amsterdam: IOS Press; 2002.

34. European Commission. Report from the Commission to the Council and the European Parliament on the state of the internal market for services. Brussels: European Commission; 2002.

35. European Commission. Proposal for a directive of the European Parliament and of the Council on services in the internal market. Brussels: European Commission; 2004.

Submitted on 01/Aug/2006

Approved on 14/Sep/2006 